https://doi.org/10.37816/2073-9567-2021-60-208-223

УДК 821.161 .1 .0

ББК 83.3(2Poc=Pyc)6

This is an open access article distributed under

the Creative Commons Attribution 4.0

International (CC BY 4.0)

(C) 2021. Yu Gao

Harbin, China

\title{
BLACK HUMOR IN DANIIL KHARMS'S WORKS
}

Abstract: Daniil Kharms's works have been a hot topic of research worldwide for several years. The present study discusses Kharms's black humor writings of the 1930s, exposes aesthetic potential and humanistic content of black humor as an avant-garde phenomenon, and defines the role of black humor in the plot of works containing allusions to arrest in secret, hospitals and the life of Soviet children. As paper suggests the themes and subjects of Kharms's black humor are designed to enhance humanistic content. In Kharms's art world of black humor, "purity" is a kind of harmonious world order representing the earth as "a space, filled with madness and fear" on a real level while on an artistic level it functions as the purity of creative mind generating circular compositional structure and using semantic shift and narrative interruption. In other words, purity embodies the real world while belonging to it. The popularity of Kharms may be, firstly, explained by a clear feeling of absurdism and black humor, the root of which is his requirement for humanization of life and firm faith in God. Kharms believed that religion is "ambiguous and amorphous" and should be expressed in some form or object, without which the essence of religiosity would be lost, even if the most reliable authority and firm dogma are there. Thus, overtly inhuman elements which give a false impression of writer's spiritual value, do not express the essence of his worldview, but reflect surrounding senseless reality. Out of dissatisfaction with reality, Kharms uses black humor to respond to the evil and absurdity of life.

Keywords: Daniil Kharms, black humor, absurd, reality, humanity.

Information about the author: Yu Gao — Doctoral candidate, Heilongjiang University, School of Russian, Xuefu Road, 74, 150080 Harbin, China. ORCID ID: https:/orcid. org/0000-0001-8388-0303. E-mail: 15776609418@sina.cn

Received: August 10, 2020

Date of publication: June 28, 2021

For citation: Gao Yu. Black humor in Daniil Kharms`s works. Vestnik slavianskikh kul'tur, 2021, vol. 60, pp. 208-223. (In English) https://doi.org/10.37816/2073-95672021-60-208-223 


\author{
(C) 2021 г. Юй Гао \\ г. Харбин, Китай
}

\title{
ЧЕРНЫЙ ЮМОР В ТВОРЧЕСТВЕ ДАНИИЛА ХАРМСА
}

\begin{abstract}
Аннотация: В последние годы творчество Даниила Хармса стало «горячей» темой филологических исследований во всем мире. В статье анализируется «черный юмор» в творчестве Хармса 1930-х гг., раскрываются эстетический потенциал и гуманистическое содержание черного юмора как авангардистского явления и определяется роль черного юмора в сюжете произведений, содержащих аллюзии на арест, больницы и быт советских детей. Высказывается предположение, что темы и предметы черного юмора у Хармса были призваны усилить гуманистическое содержание его произведений. Важной категорией черного юмора Хармса является «чистота» как своего рода «гармоничный» миропорядок, на реальном уровне представляющий собой землю, как «пространство, наполненное безумием и страхом»; на художественном уровне - как чистота творческого разума, создающего круговую композиционную структуру, использующего приемы смыслового сдвига и прерывания повествования. Иначе говоря, «чистота» у Хармса олицетворяет реальный мир и принадлежит к реальному миру. Творчество Хармса вызывает читательский и исследовательский интерес прежде всего абсурдизмом, определяющим его черный юмор, в основе которого требование гуманизации жизни и твердая вера в Бога. Хармс считал, что религия «аморфная, лишенная контуров», но должна иметь выраженную форму, без которой утрачивается существо религиозности, даже поддержанное самым надежным авторитетом и твердой догматикой. Таким образом, откровенно бесчеловечные элементы, которые дают ложное представление об авторе, не выражают существа его мировоззрения, но являются отражением окружающей бессмысленной реальности. Хармс ответил на зло и абсурдность жизни черным юмором.
\end{abstract}

Ключевые слова: Даниил Хармс, черный юмор, абсурд, реальность, гуманность. Информация об авторе: Юй Гао - аспирант, Хэйлунцзянский университет, Институт русского языка, Сюэфу ул., д. 74, 150080 г. Харбин, Китай. ORCID ID: https://orcid.org/0000-0001-8388-0303.E-mail: 15776609418@sina.cn

Дата поступления статьи: 10.08.2020

Дата публикации: 28.06.2021

Для цитирования: Гао Юй. Черный юмор в творчестве Даниила Хармса // Вестник славянских культур. 2021. Т. 60. С. 208-223. https://doi.org/10.37816/20739567-2021-60-208-223

\section{Aesthetic mental mechanism of black humor}

In the world of universal standardization, black humor is a pithy paraphrasis of fundamental ideas of the postmodern literature as well as the motives of rebellion and freedom that prevails among existentialists. Black humor can be traced back to ancient Greek. According to Plato, humor "can be expanded into a mixed feeling of pain and pleasure" [22, p. 213]. Following this interpretation, Darwin distinguished primarily and secondary forms of laughter: different from primary laughter, which brings joy or happiness in states of play, 
"secondary laughter seems to arise and associated $<\ldots>$ with a specific emotional pleasure in experience which would be frustrating or distasteful if taking seriously. This laughter and this quality of feeling are the kernels of what we called humor" [22, p. 213]. Proceeding from the perception of the world as absurd and chaotic, combined with the rigidity of social norms, black humor denies the consistency of choice and individuality, which is central to existentialism and related to misanthropic humor, and through this, it finally evolves into the only truly human reaction to the general absurdity of being. Therefore, secondary laughter and its unique psychotherapeutic effect serve as the motive of black humor, which reveals the object of its amusement in overturning moral values that cause a grim laughter. Black humor causes laughter, in situations where any other forms of description would only bring crying [2].

Among literary terms, term black humor was coined by the Surrealist theorist Andre Breton in 1935 while interpreting the writings of Jonathan Swift, publicly known as a literary school of American prose from the 1950s and 1970s, is akin to absurdism [9, p. 1199]. From the Mid 1950s, a group of young writers named the "avant-gardists" including John Barth, Thomas Pynchon and etc., focused their writing on "city culture", deliberately displaying mediocrity, triviality, and absurdity to reveal the spiritual anxiety and perplexed emotions of modern people. According to Borisov, in Russian tradition black humor appeared in Russian literature at the beginning of the twentieth century following the translation of the German book "Stepka-Rastrepka" by G. Hoffmann-Donner in 1845, which was reprinted more than ten times before 1917 [2]. "Stepka-Rastrepka" is full of intimidating characters. Although it portrays the cruelty and inhuman culture of death, it lacks some inherent features of black humor that should be strengthened and further developed. More mature work of black humor appeared in Russia in German humorist Wilhelm Busch's "Max and Moritz", which had a major influence on the moral development of young people. Thus, "Stepka-Rastrepka" and Busch's works serve as the prerequisite to Russian black humor.

Daniil Kharms (1905-1942) is the preeminent author of Russian black humor [2]. There are definite connections between Kharms's works of the 1930s and 1940s (after arrest and exile to Kursk) and the black humor of the latter half of the 20th century in America. Kharms abandons traditional narrative discourse in a mocking and ironic tone and creates harmonies between absurdity and solemnness, exaggeration and reality, farce and seriousness. The time when Kharms's work was translated into English by Gibian and made it available in US and UK in 1971, American journal "Choice" praised him as his "stories range from funny to macabre and black humor in an impressive display of imagination" [19, p. 1458]. Borisov also emphasizes this feature as an important influencing factor in D. Kharms's work, which "has led to increased prosperity of black humor in the 1970s and 1980s" [2].

Kharms appreciated German humorist Wilhelm Busch's humor style. According to Kharms's sister, his favorite childhood reading was Busch's children's book. By analyzing children poems of Kharms and Busch, we can find textual links between their humor writings. Kharms's imitation of Busch's "Plisch und Plum" was clearly evident in "Kryskow and two dogs".

"Plisch und Plum" tells about the antics of two puppies and their little adopters. Through training, puppies stop being naughty, at last even sold at high price. Busch gave a detailed description of puppies' antics: "And behind the mouse at full speed / Plisch and Plum are running with barking. / The mouse is running/Dogs are behind it. / The mouse can't get away from dogs. / Along the way/Violets, / Poppies, / Dahlias / And tobacco" [13, 
p. 93]. Busch's humorous poem was first published in 1882, then was translated to Russian by Kharms in 1937. Kharms's translation was made on the basis of his poem "Kryskow and two dogs" in 1935, which also refers to two dogs, Bim and Bom, who brings owner quite a lot trouble. Humor style and plot in Kharms's poem were obviously influenced by Busch. While Kharms left out plots and background about the characters and event with the help of succinct description of series actions and dialogue, directly rendered the climax and result: "But because of the bone marrow/Suddenly a fierce battle begins. < .. > And two dogs cry bitterly:/This is what fights lead to" [13, pp. 47-48].

We can see that in "Kryskow and two dogs" there is not so much a plot as a series of events held together by threads of character and violence and strange turns of phrase. On the contrary, in "Plisch und Plum" by discussing the relationship between pets and their owners, Busch also aims to encourage parents to nurture children on the basis of patience, but not scold. Busch's esthetic reception is of some educated function in the process of building harmonious relationship. While in Kharms's poem by using the "funny catastrophe" and skipping cliche storyline, a double effect of aesthetics has been presented, and reveals inherent feature of Kharms's black humor writing. On the one hand, to some extent Kharms's poem can be reviewed as after story of Busch's. Two dogs helped new owner find tobacco and matches, at last they cannot escape the fate of abandoned. Kharms does not aim at moralizing ideology, but aim at rethinking traditional causal association. On the other hand, two dog's injury and tragic event are presented in a deliberately light form, which gives the impression of absurdity. It seems like for Kharms sadistic even black humor and inhuman elements are only way to survey the long windings of destiny.

Main feature of black humor is considered as "crying laughter", which serves as marked characteristic of most Kharms's humors and stories. In Kharms's creation disappearances and deaths indeed are told with eerie laughter without pity and that kind of humor becomes an obligatory constructive element in Kharms's whole art world. By this principle, his black humor is a combination of laughter (an emotional component) and cruelty (a thematic component) [2]. Therefore, it is necessary to emphasize the secondary laugher's function in his text to mark the boundary between death and life.

Here, Kharms's final work should be mentioned. In final prose "Acquittal" (1941), he described a murder in detail in the first person (how "I" tore a leg from a man, tore ahead from a baby, and raped a pregnant woman). The light-hearted tone of the message (beating people to death) and trying to present as mounting a defense in court can be considered as indicating a lack of guilt. He called the murder a trivial crime ("пустяшное преступление"), which recalls the "trivial thing" (“дело пустяшное") of Luzhin in Dostoyevsky's "Crime and Punishment" (1866); Luzhin called the false accusation of theft that he leveled against Sonya a "trivial thing". He dug a pit for the miserable harlot and her poor family to cast himself as the innocent victim of a hate campaign. Furthermore, the scandalous behavior of heroes also recalls Svidrigailov in "Crime and Punishment", who is a thoroughly evil person, a rapist, a poisoner, and a destroyer. There is no compunction of the two perpetrators about how they remorselessly tortured people, especially women and children.

"Acquittal" can be seen as presenting a kind of universal abuse not only in the individual but also of human logic. Commenting on other stories of Kharms, Anemone found that, it "can be read as Kharms's confession of the radical avant-garde's role in the moral collapse and indiscriminate violence of Stalinism" [18, p. 88], presenting the seemingly incongruous image of the narrator humbly bowing his head. 


\section{Black humor and dark reality}

Initially, to avoid censorship, Kharms's black humor stories were legally published only as children's literature. The writer could realize his creative ambitions for black humor only in children's literature. For instance, in "Fairy tale" (1935), the king melted the stove to burn the queen. The queen crept behind and pushed the king, then the king flew into the stove and was buried there. Accordingly, death-describing works characterize Kharms's body of work. The most mysterious death presented in his black humor writing appears in "The falling" (1940), in which 3 Ida Markovnas leaned out of a window and fell from the roof, struck the ground with their arms spread and eyes agape. Death, violence, and cruelty are presented by the writer only as a reason for fun. It is not surprising that people brought up in the same system of values instinctively rejected such humor.

In Kharms's black humor writing the "inhumane factor" serves as spiritual core, which gradually reveals his attitude toward real life. In his stories, the weaker character is always the victim of elder or stronger characters. For instance, in "Patin and Kulagin" (1939), Kulagin died as a result of being tortured by Patin. As Meilakh found, it seems that "we need to get a grasp of Kharms, plunge into this horror of communal apartments, into this cruelty of Soviet life. His cruel texts are a way of exposing the cruelty of life around him" [8].

It is pointed out in "On laughter" (1933) that there was both average and strong laughter, with the latter being better. Strong laughter is one part of a hall who may laugh at full volume, while the other part of the hall remains silent. It is a black and white world to Kharms: when someone laughs, others keep silent. For him, black humor serves as a narrative discourse for forcibly extricating himself from despair. As Max F. Schulz reveals that an aesthetic pleasure of black humor comes from the proper imitation of its fictional world, from the exquisite technique of reflecting the deep and complex rifts of contemporary life through these fictional tiny worlds [14, p. 42]. Therefore, Kharms's black humor writing combines a literary aesthetic mechanism and his ideological connotations, and it is the combination of ridiculous reality and desperate comedy.

Kharms official started create black humor after his first exile (1931-1932), which had a great impact on him. He was strongly discontented with the dark reality of the Soviet Union, and these ideas and psychological and moral implications run through his fiction after exile. The emphasis was on the external manifestations of inhumanity, horrors, and sadism. It seems that "The thing" (1929) is an intimation of life in the Soviet Union in the 1930s, in which he describing a mother kept saying she could see someone on the street looking through the window, and the father convinced her that nobody could have been looking through the window, even after he noticed a man with a dirty coat and a big knife in his hand trying to get in through the window. Deep background knowledge is required to understand the father convincing the mother that "There is nobody", which signals the writer's uncanny feeling of being spied and his angry and helpless life. This act of convincing reflects the dark humor Kharms sees in his situation: he was walking alone in the darkness. We can also find his increasingly visible dissatisfaction with the government in his dialogue with friends in 19331934.

Lipawski: Should we commit crime or so-called betrayal on the back road?

Kharms: I have already committed it once today, but I am ready to do it a second time [6, vol. 2, p. 195].

Kharms's resistance to ruthless and unsparing Soviet policies is directly reflected in his prose after arrest. In "Olga Forsh approached Alexei Tolstoy..." (1934), a stinging satire on 
the Writers' Union of the U.S.S.R, Kharms also injected black humor into rather a formidable subject, pointed out that "they didn't find a stone, but they found a shovel $<\ldots>$ With this shovel, Konstantin Fedin struck Olga Forsh on the face" [7, p. 341]. Later, the unidentified "they" who might be considering a similar course of action appeared again in "Dream" (1936). The sanitary commission, walking around and seeing Kalugin, found him unsanitary and worthless. Then, they folded Kalugin in half and threw him away like rubbish. From the viewpoint of Kharms, the Soviet authorities are sneaky, such that everyone is likely to be destroyed. It is obvious that in Kharms's black humor writing community "they" serve as the figure of the Soviet authorities and dark reality. His writing includes "black humor and arrest in secret", which had never been presented in literature before him.

At that time Kharms was exposed to various stressors, including incarceration in secret arrest and conflict with the criticism of his children's poems from proletarian critics. In "Kalindov" (1930), Kharms implied that the government-controlled people by strict surveillance. Kalindov maintained a strange stare for an extended period. "My patience ran out; I screwed up my eyes and booted Kalindov in the face. When I opened my eyes, Kalindov was standing in front of me, his face bloodied and mouth lacerated, peering at me straight in the face as before" [20, p. 7]. During perestroika from inside the KGB (КГБ) we known that Kharms was arrested in 1931 on charges for the creation of counterrevolutionary work because of OGPU (ОГПУ)'s exaggeration, distortion and fabrication of the information about OBRIU (the so-called illegal a group of anti-Soviet children's writers) [7, p. 629]. Kharms continued to write for children's magazines when he returned from exile, Soviet authorities, having become increasingly hostile toward the avant-garde in general.

In the children's poem "A man came out from house..." (1937), Kharms satirized real social abuses by creating a story in which a person entered the dark forest and then suddenly disappeared. Kharms's poem failed to meet the standards of social Soviet values, and as a result, he was prohibited from publishing and thus lost a source of livelihood. In 1937 Marshak's publishing house in Leningrad was shut down, some of employees were arrested: Alexandr Vvedensky, Nikolai Zabolotsky, and later - Kharms. It is thus evident that the Soviet secret police agency was responsible for the accident and responded to resistance with serious abuse. As Meilakh points out, "The GPU was especially interested in abstruse works in which they saw 'the encryption of anti-Soviet agitation' or, as they wrote, 'encryption"' [8], which appears in zaum (заумь) and avant-garde narration.

"The Obstacle" (1940) was written almost entirely in dialogue. It echoes the everyday experience of the time in Soviet Russia when one's intimate life intersected the absurdity of the system.

The man in the black coat locked the door of Irina's room and sealed it with two brown seals.

- Outside - he said.

They all went out of the flat, loudly slamming the outside door [20, p. 62].

In the implicit description of "come with us" and the unspoken misery of the novel's leading characters in the text, Kharms's strong criticism of arbitrary arrest is visible. At the time, any comments about sweeping power were ideologically sensitive; therefore, arbitrary arrest, detention, and sanguinary rule are presented by a brief description of dialogue, and the core of this story is covered by sexual innuendo. "The Obstacle" is considered to be a satire and sarcasm of Soviet society. Moreover, Kharms's family learned of the manner of his death from the KGB [8], which is true black humor. 
There is another interesting type of black humor in Kharms's work, specifically, hospital black humor. The absurd was usually presented in such black humor writing using the theme of doctors. In "Comprehensive Research" (1937), to gain a universal recognition of death and existence, a doctor murdered his patient with poison.

Doctor: You have swallowed the research pill.

Yermolayev: Save me. Oh. Save me. Oh. Let me breathe. Oh. Save... oh. Breathe...

Doctor: He's gone quiet. And he's not breathing. That means he's dead already. He has died, not finding on earth the answers to his questions. Yes, we physicians must comprehensively research the phenomenon of death [20, p. 39].

The reality in Kharms's artistic world is no different from the reality of psychiatric hospitals, and black humor is an alternative to the dark world. The doctor mirrors Kharms's logic of existence, which situates creativity and freedom in the rejection of the norms of daily language and logic. "Freud included roles of grammar and semantics among such conventions and restraints. But they also include roles of behavior, for example, politeness, and many other things which, by habitual psychological association, in society, culture, and art and our general picture of life, are considered to be universally recognized, unquestioned and fixed" $[18$, p. 23]. In culture and the views of the public, the doctor has a profession that saves lives and heals wounds, but if the doctor stops prioritizing human being's needs and considerations, the doctor who manipulates life may diverge from the humanitarian path and become a killer. The combination of harrowing words and behaviors in Kharms's black humor writing is an outward expression of his critique and satire of the darkness of reality and the decadence of the soul.

Gerasimova found that it is better to describe these inhuman and indifferent elements as laughable, which is characterized by foolishness. Black humor is the joke of a person in a hopeless situation. The roots of black humor are sought in a person's fear of death and the attractiveness of all that is connected with it. As Gerasimova states, all things can go back to the human reason, to the helplessness of "human" being in the face of deep ontological problems [3, pp. 11-12].

In the 1930s, it is very unlikely that any interesting work by Kharms was read by the general public. In his second half of life, he did not show his work to anyone out of his limited social connections. In Kharms's prose, black humor takes other directions; unlike funny or scary stories; these are short, deliberately incomprehensible stories. The description of some events cannot be understood due to the use of hieroglyphs, as if Kharms intended to bring a meditative state to life, by forcing the reader to think about the incomprehensibility of the world.

\section{- The realistic level of black humor}

We believe that the avant-garde artistic techniques and black humor in the works of Kharms, have an unavoidable paradox that reveals the situation of having "nowhere to go" in real life. Disappointed by the collapse of his metaphysical project of purifying the word and world in real art, Kharms, in his prose of the 1930s, comes to the same pathos of despair and desire for nonexistence, for destruction.

As Jakovljevic found, “as so many of Kharms's characters do, Vanya and the old lady depart from a certain physical location, most often home, then they drift away, forgot what they were looking for and who they were, disappear and end of forgotten. They seem 
like strange amnesiacs able to hold onto only what happens in the moment. This moment, precisely, is the nowhere: anagrammatized" [21, pp. 169-170].

Kharms, from the perspective of different heroes, expresses his idea of reality and art in the literary text using bible themes. In the play "Falling, or Knowing Good and Evil" (1934), he referred to the "Paradise tree", which was decorated to resemble the tree of knowledge in the Garden of Eden. Eve and Adam ate the forbidden fruit, they were able to tell what was good and what was bad, thus learning many things that they did not know before. But for God, knowing good and evil serves as the entry of sin into humanity.

FIGURA. You, man, and you woman, you have eaten forbidden fruit. And so, get out of my garden.

ADAM. Where do we go?

EVE. We are not going anywhere [6, vol. 1, p. 202].

In Jewish tradition, the tree of knowledge and eating its fruit represents the beginning of mixing good and evil, of black and white, of life and death. The above quote conveys the real circumstances of the existence of avant-garde artists in the Stalin period. Adam is similar to Kharms's friends, who were abandoned by fate. The world of mixed evil and good serves as a situation of dark reality in which Kharms and his friends found themselves greatly confused. As Kharms declared in diary (1933) "Everything is disgusting to me/Instant and eternity" [6, vol. 1, p. 143].

We can also assume that for Kharms the image of this reality is fundamentally illogical - or rather, super logical. His reality is comprehensible with the help of spiritual practices that allows us to perceive not only daily sensible events but also supersensory events. The image of Eve is close to the writer. Kharms's refused the terrible situation of "nowhere" and attempted to sift through the mixture of good and evil in the world to extract and liberate the sparks of holiness trapped therein.

Avant-garde art is also a kind of temptation. It returns the word "art" to its original meaning, associated with art and temptation. For Kharms, the absurdity is the apple in Eden, which has the power to help him telling good from evil, comprehend reality and art, and understand the highest purity and path to salvation. It is pure not only in Kharms's conscience but also in artistic creation. Reflections on purity can be found in his diary of 1933. In his viewpoint, the real world is in chaos, which spurred him to change irrational relations. However, he began to pursue the harmonious order of the universe and establish a normalized order. He thought that the correct order can be ascribed to purity. "This purity is the same in the sun, in man, and poetry. True art is among the first. It is necessarily real" [12, p. 80]. In Kharms's art world, "purity" is natural and universal, is displayed on a real level as in the understanding of the earth as "interspace, filled with madness and black humor", is displayed at an artistic level as purity in the mind, and is expressed as having a circular structure, with a shift or interruption of cause and effect.

In a letter to Pugachov (1933), Kharms said that he doesn't know the right word to express that strength in Pugachov which so delights him. He usually calls it purity, then calls the new world order the order of Purity. According to Tokarev, Kharms's poetics is based on his desire to comprehend the highest reality, valued by poets as the first order, which can manifest itself to the greatest extent only whenever in "pure order". Tokarev also claimed that the method of poetic reduction is one key feature of Kharms's poetry. "Kharms developed a method of cognizing the transcendental, which can penetrate deep into the sphere of thingsin-itself, in which exists the 'pure' object with $<$ the fifth essential meaning $>$, meanwhile, 
both of them determines its being, has its own equivalent in the system of the whole concepts so-called 'pure' word" [10, p. 177].

Kharms always looked forward to recognition by readers and society. Faced with a barrage of Schwartz's jokes (e.g. everyone in Tiflis knows Zabolotsky and hardly anyone knows Kharms), he lost his temper and wrote in his diary that "I will be more historically important than Schwartz and Zabolotsky; I shall leave a radiant mark upon history, while they will quickly be forgotten" [20, p. 67]. To maximize the impact of humanistic spirit and deep humanistic concern, he intentionally created varieties of black humor to broaden his idea's appeal. In a word, purity embodies the real world and belongs to it meanwhile. "The order in this context is something completely special, it is a kind of harmonious order, a form that can be arranged from one object to another, permeate the order of things without any understanding and participation" [17, p. 353].

\section{$3 \quad$ Black humor about child}

Kharms truly treated children and senior people (especially old women) very negatively. On his desk, there was a lamp with a shade on which he had drawn "a house for the destruction of children". He claimed that "harassing children is cruel, however, something has to be done with them" [7, p. 359]. Furthermore, he expressed the idea that it is necessary to teach children cleanliness from an early age by, for example, putting an iron sheet with sand near the stove, which is not difficult at all. In prose, Kharms even made up a Utopian kingdom, that was filled with a terrifying disgust of children. During emperor Alexander Wilberd's reign, showing an adult to a child was considered the highest insult. It was considered even worse than spitting on someone's face that then flowed into one's nostrils. Then, he developed a plan for the destruction of children. In prose "They call me a Capuchin" (1938), Kharms elaborately described how to measure it: "I certainly know that they should not be swaddled at all - they should be obliterated. For this, I would establish a central pit in the city and would throw the infants into it" [20, p. 46].

Nemirovich-Danchenko identifies three structures for thematic types of "sadistic quatrains". We need to point out that in Kharms's children's black humor, there exists the complication of second thematic type of SQ — "the hero brings people around his death and destruction" [2]. In "The Old Woman" (1939), Kharms described a hero with a strong dislike of children and tried "thinking up various means of execution for them, $<\ldots>$ to infect them all with tetanus so that they suddenly stop moving" [20, p. 83]. It also should be noted, that here, black humor serves as a satirical grotesque: the hero's murder of an old woman and his inward disturbance after the killing can be seen as an alien parody of Raskolnikov's psychological activity in "Crime and Punishment". In textual research space, there is no measurement to calculate the writer's realistic position of child, there is writer's rethinking of human existence reflected from children's black humor. After he has sensed life's anguish, he affirms the meaning of life's value through the rebel against fate. The black humor in Kharms's novella set foot in feeling of individual life and striving with a multiple-level structure.

The reason for his dislike of children and old people was the "instinctively sensed their approach to death — the beginning and ending" (original: Возможно, он инстинктивно ощущал их (детей и стариков) приближенность к смерти - как с одного, так и с другого кониа - translated by author from Russian) [4, p. 288]. In “Article” (1936-1938), he once suggested that children are similar to old people, as children are at most to cruel and naughty old people: "the affection for children is almost the same as the affection for an embryo, and the affection for an embryo is almost the same as the affection for excrement" 
[12, p. 23]. What people loved and respected brought only disgust in Kharms. In terms of function Kharms's black humor writing is close to Bakhtin's view of laughter, which marks the boundary between the living and the dead and between kindness and cruelty.

Bakhtin noted that excrement played an important role in the ritual of April Fool's Day, during the carnival solemn service the chosen clown bishop fumigated with excrement in the church. The image of excrement in the sedateness, full of realism, irony, and grotesquery, represents the complex, colorful and dramatic life of the contemporary Russians. The leading feature of Kharms's grotesque works is decline, which is reflected in various carnival forms (for example, the debunking of the carnival king, swearing, death wishes, throwing mud, excrement, etc.) Bakhtin considered laughter culture as a drama of bodily life (copulation, birth, growth, eating, drinking, excrement), he regarded cursing, wishing for death and excrement to be grotesque images that characterize the phenomenon of death and birth, growth and formation [1, p. 82]. In Bakhtin's viewpoint, birth and death are not only an absolute beginning and end but also moments of its continuous growth and renewal. Therefore, one should laugh, need to laugh even when it is already impossible to keeping continuity. Kharms has also convinced Bakhtin's concept of "continuous growth and renewal", deems that only cattle don't need to laugh.

By providing life a unique way of amusement, revelry aims at celebrating people's temporary cancellation of the current dominating systems and the caste system, as in Kharms's carnival game "Knights" (1940). In this prose, killing is justified by Kharms as a means of expressing anger and releasing hostility; the doctor tied curious old women, he grabbed the pincers, engaged her jaws, and tore them out.

For Kharms, the mixture of old mad women and "young, healthy and full women" is a metaphor of the world. In the interesting addition to the promotion of health, youth, and strength, some painful, gloomy elements can be incorporated into the official propaganda mentions and materialism in the USSR, and mysticism and decadence in avant-garde art. He deliberately created a dark, gloomy world of mental deviations, and the physiological and emotional causes of his disgust were positive functions. There is an internal consistency of all these complex emotions. The image of "young, healthy, full women" is not only a grand display of attractiveness to man but also preparation for a new generation that has been withheld from the old woman. The child combines Kharms's mental deviations in his conceptions of death and life.

It is not difficult to find the genre of black humor involving the activities of old women and children. His "The start of a very nice summer day" (1939) highlighted the lack of family values; thus, children were quite mistreated by their own mothers.

A big - nosed woman was beating her child with a trough. And a young, plump mother was rubbing her pretty little girl's face against a brick wall. $<\ldots>$ A small boy was eating something revolting from a spittoon $[20$, p. 53].

Kharms was tortured by what had happened, scars on the souls and bodies of the innocent, and the following weakness are unavoidable. Early in the 1930s, Kharms wrote an essay stated "I decided to mess up the party...", which revealed his dislike of children as the symbol of innocence, and he admitted that "Children are another matter. They are usually said to be innocent. And I consider that they might well be innocent, but anyway they are highly loathsome" [20, p. 71]. In his black humor writing human suffering and death are symbolized by the innocent children being sacrificed as part of the future. Therefore, Kharms tried to 
portray the sufferings of cadres and intellectuals during the tragic experiences from the late 1920s until his death. To some extent, "death inspires both the writer and his characters to gloomy joke" [2].

Kharms kept a distance from the government so that policies could not interfere with him, but he concerned about social reality. He regarded black humor as a more serious humanitarian concern for people's sufferings than malevolent inhuman spirits. In "A sonnet" (1935), Kharms used children's black humor to reflect the sharp and stinging social issue of indifference. In prose, people stopped arguing when a child fell and broke his jaw. However, the wounded child can only pique people's curiosity but fail to evoke their sympathy. The interpersonal coldness makes people feel quite inhumane even in the parent-child relationship. In his fiction, cruelty to children is the highest manifestation of inhumanity and represents complete disbelief in the future. Therefore, in prose, Kharms declared that children can be composed and created with the help of vivid examples with hands.

Statement of "Kharms dislikes child" cannot be taken seriously. On the one hand, Kharms's rejection of borderline physiological status (childhood and old age) was affected by Plato's view of Eros. According to Yampolsky, the essence of Plato's Eros, which is an enemy of old age, shuns the very sight of senility as far as possible and clings to youth and beauty, consists in the striving for highest level of being [17, p. 223]. Therefore, not childhood and old age but youth serves as Kharms's source of creativity and aspiration of infinity and continuity. On the other hand, the provocative nature and nihilistic value of the avant-garde spirit prevented his work from displaying humanity, such as V. Mayakovsky's shocking statement: I like to watch the death of children.

The relationship between father and son also appeared in Kharms's black humor. In the poem "The parents gave birth to a son" (1931), a father protected his son by saying demeaning thing such as "how lousy he is" or something "about the disgust of the newborn", meanwhile hiding the father's pride and contentment toward his son. In Russian traditions, such irony is seen in the superstitious belief of saving a good fortune. Researchers have found that father's pretense makes us recall folklore of " "preserving' the newborn from the evil eye and evil spirits by swearing the baby. Thus, Kharms's black humor, coincides with Russian traditions, is 'superstitions' in the new era" [5, p. 94].

Therefore, similar to the derogatory comment about the newborn made by his father, Kharms's dislike of children is only a mask. Meilakh also indicated that Kharms's dislike of children was one of his masks. Friend of Kharms's mother was a midwife, which is why Kharms knew a lot about birth and was familiar with the details of a child's life. In addition, children's sensations of adoration are an accurate summary of mutual interaction. "Children sincerely adored Kharms, and they don't make mistakes. Kharms was a deeply vulnerable man. He was hurt by vulgarity, which was one of the main themes of his later prose" [8]. In essence, the dislike of children in Kharms's avant-garde art is a game aimed at restoring human freedom on the one hand, and neutralizing its resistance because of its attitude of game on the other hand. Briefly, the key that makes his works unique lies in paradox of his attitude and resistance.

\section{- $\quad$ The faith level of black humor}

For Kharms, the image of a child is a symbol of the future, humanity, and the miracle of life. However, he describes in detail the mechanism of children's black humor based on the principle of the destruction of expectation and the clash of official children's poetry with unmotivated cruelty. As Druskin claimed “purposelessness is in general one of Kharms's 
characteristic qualities, $<\ldots>$ miracle for him was similarly purposeless. For Kharms the most important thing had always been not art, but life: to make his life into art" [18, p. 22].

Kharms's path to absurdity is closely related to his peculiar understanding of "miracle" and "horror" in real life, which serves as a turning point during his writing career. As Druskin found, when Kharms initially went into literary creation, he "had a sense of life as a miracle and he wanted to make his life into a miracle. This is why miracles feature in many of his stories" [18, p. 22]. However, from the quote from "The Old Woman", we can see his interior monologue. As it is written at the beginning, "it will be the story about a miracle worker who is living in our time and who doesn't work any miracles. He knows that he is a miracle worker and that he can perform any miracle, but he doesn't do so" [20, p. 83]. The monologue at the same time is also an autobiographical confession and philosophical reasoning, which inflected a person who was no longer able to cry, who would then respond to aggression with laughter. This is similar to how surrealists and dadaists turned their derogatory humor into a defense mechanism against a monstrously gloomy and uncontrolled reality, and this defense is responsibly aggressive, mocking and frivolous.

Although the historical situation did not allow for the existence of miracles, Kharms was waiting for a miracle, in diary mentioned his hope that everything would be in peace. However, there was no miracle, and in fact, people were scared of everything. Kharms had already become disappointed in his ability to work miracles, and that left him no choice but to resort to black humor. "A person may live in religious, a-religious, or anti-religious automatism - and the first kind is not better and the last maybe even worse. Kharms exposes not the petty bourgeoisie, not the philistine, but the automatism" [18, p. 23] of thought, feeling and everyday life. For Kharms, laughter functions as a force exposing seriousness and continuity, showing us the metaphysical view of the laughing man. If black humor can still be imagined to be a form of defensive reaction to the world, then cynical laughter is already an attitude toward the world and is almost a worldview that denies shame, compassion and pity as inappropriate to the interests of the personal self.

Laughter is intentionally added to the image of a dead body, bullying, and inhumane torture that does not aim at exhibiting shallow theme of the delight experienced by the psychologically abnormal person but at testifying to the underlying theme of black humor. The core of Kharms's black humor lies in exposure to death and ugliness, but does not entail that Kharms had faith in the devil but rather proved his resistance to the devil. Kharms believed that a person who is in a dilemma should be pushed to fall, when he gets up, he will begin a new, completely different life. His breaking is preparation for making.

The statement that "trivial thing and only God knows how it would go" of Dostoyevsky, known by the declaration of "stay with God", serves as a symbol of faith in God. However, in "Crime and Punishment", God merely organized a test of faith for Sonya and then arranged with Raskolnikov to detect Luzhin's attempt to deception, defending her against the accusations. Eventually, Raskolnikov proved to the public that Luzhin was a pompous ambitious freeloader. Similarly, through Kharms's "Acquittal”, we can see the writer's final relation to God and his philosophical reflection. At the end of the black humor story, the cruel assassin was accused of murder and bloodthirstiness, and his defense counsel worried that he would serve a prison sentence. The result proves Kharms's attitude toward evil: the final trial must compensate fairly and deter infringers, and justice will be served. Kharms tried to strike a powerful counterblow to inhumanity and its symbol to make people laugh in his way.

However, what makes people misunderstand Kharms being directly connected to devilry, which blows with demonic coldness and depravity? In most avant-garde works, such 
as those of Kharms, absurdity dominates meaning, and individuals appear in alienated forms and are hostile to themselves, revealing the properties of anything but a person. "Avant-garde fervent or consciously religious content has trailed away to nothing. The reason of deficiency of the faith in God is not due to the ignorance of religion, but because the religious consciousness is trying to escape from its contradiction by escaping to straighten and rationalize the original paradox of faith, which gives rise to the dangerous tendency of religious unconsciousness in the avant-garde - the withdrawal into amorphousness, the transfer of divine features onto the material object" [16, p. 11].

There are two sublime things in Kharms's life: humor and holiness. "Kharms interprets holiness as truly alive life, interprets humor as unauthentic, frozen and already dead life: it's not life, but only a dead outer form of life, an impersonal existence. In his work Kharms does not moralize but laugh, and his laughter is no less horrible than the laughter of Gogal" [11, p. 398]. As asserted by Bakhtin, folk laughter help people get rid of horrors in front of the holiness [15, p. 182]. Simultaneously, religious unconsciousness is also one of the preserving qualities of religiousness, preserving the continuity of Kharms's literature logic. Religiousness often disappears in Kharms's belief, and then, the willingness to accept the absurd began to serve as the evidence in favor of faith. For Kharms, faith itself is more profound than any specific religion, and his black humor writing allows readers to reappreciate his contradiction of faith.

The popularity of Kharms can be partly explained by the clarity of his absurd and black humor, the root of which is the humanity of the ordinary person. The denial of absurdity is more likely as characteristic of types prone to successful socialization by adhering to a declared value system, which is essentially arbitrary. A repressed, alienated person is certainly understandable to some extent at the stage of understanding his alienation [16, p. 13]. However, Kharms's search extended far beyond the limits of everything and every social field. The denial of external repressive social values and the denial of other values for an "ordinary person" is extremely difficult to reject. Kharms attempted to create black humor stories to search for the hermit inside of himself and encourage others to focus on self-reflection.

\section{Conclusion}

Dluskin regards Kharms as the brave boy who saw the insignificance and emptiness of mechanized life, was tired of automatism in understanding the world, and was bored of living the same life every day. Many works of Kharms inherently combines the elements of evil ridicule of the stilts of ideals, the pattern of vital interests, and the predictability of social behavior. There exists so-called nonsense and illogic in Kharms's stories and poems, not because his stories are meaningless and illogical but because the life that he described in it is existentially meaninglessness or, as he stated, accept the world just for what it is. The formal meaninglessness of situations and things, as well as black humor, are means of exposing life and expressing the real nonsense of an automated existence and the real states that are characteristic of every person.

Kharms's stories always retain something incomprehensible to the end; they laugh, but the reason for the laughter cannot be explained. The description of this sensation is similar to Kharms's definition of the perfection of infinite stuff: when everything is clear in a thing, it ceases to be perfect and is therefore interesting. Kharms found relativity both in the straight line and in the curve. He claimed that a straight line is perfect, but limiting it on both sides, it is simultaneously imperfect. Therefore, it may be such that we can grasp it freely at a glance and yet at the same time remain inconceivable and infinite, as a straight line when 
broken simultaneously at all its points is called a curve. On the contrary, Kharms's creativity constantly emphasizes the imperfection and absurdity of the world order and in contrast, his imperfection and marginality about the real world. We can see that all of his works are aimed at the redefinition of given meaning, while in the redefinition, a continuity of his literature logic exists - his belief of purity in real life and in real art. Literature relativity between continuity and purity, as a prerequisite of Kharms's understanding of himself and world, reflects the different comprehensions that human beings have of themselves and their existence.

With their constant reflection and removal from the result just achieved, Kharms appears as the general intonation that sets not only the internal structure of the work of art but also the behavior of the black humorist, who builds his existence under the laws of this paradoxical discourse of approval by doubt and overthrow.

\section{СПИСОК ЛИТЕРАТУРЫ}

1 Бахтин М. М. Собр. соч.: в 7 т. М.: Русские словари, 2008. Т. 4 (1): Франсуа Рабле в истории реализма (1940 г.); Материалы к книге о Рабле (1930-1950-е гг.). $1119 \mathrm{c}$.

2 Борисов С. Б. Эстетика «черного юмора» в российской традиции // Из истории русской эстетической мысли: межвузовский сборник научных трудов // D-harms. ru. URL: http://www.d-harms.ru/library/estetika-chernogo-umora-v-rossiyskoytraditsii.html (дата обращения: 01.05.2020).

3 Герасимова А. Г. Проблема смешного в творчестве обэриутов: автореф. дис. ... канд. филол. наук. М., 1988. 26 с.

4 Кобринский А. А. Даниил Хармс. М.: Молодая гвардия, 2008. 501 с.

5 Козлова C., Куляпин А. Отцы и дети в мире «Черного юмора»: Д. Хармс и О. Григорьев // Русская литература в XX веке: имена, проблемы, культурный диалог. 2008. № 9. С. 92-109.

6 Липавский Л., Введенский А., Друскин Я. и др. «...Сборище друзей, оставленных судьбою»: «Чинари» в текстах, док. и исслед.: в 2 т. М.: Ладомир, 2000. Т. 1. 846 c.; T. 2.749 c.

7 Мейлах М. Б. Поэзия и миф. Избранные статьи. М.: Издат. дом ЯСК, 2018. 1056 с.

8 Мейлах М. Б. Путь подражания Хармсу неплодотворен // «Коммерсантъ». URL: https://www.kommersant.ru/doc/639417 (дата обращения: 05.06.2020).

9 Николюкин A. Н. Литературная энциклопедия терминов и понятий. М.: НПК «Интелвак», 2001. 1596 с.

10 Токарев Д. В. Курс на худшее: Абсурд как категория текста у Даниила Хармса и Сэмюэля Беккета. М.: Новое литературное обозрение, 2002. 333 с.

11 Федоров Г. А. Московский мир Достоевского. Из истории русской художественной культуры ХХ века. М.: Языки славянской культуры, 2004. 464 с.

12 Хармс Д. И. Полн. собр. соч.: [в 4 т.] СПб.: Академический проект, 2001. Т. 4: Неизданный Хармс. Дополнения к т. 1-3: Трактаты и статьи. Письма.. 319 с.

13 Хармс Д. И. Полн. собр. соч.: [в 4 т.] СПб.: Академический проект, 1997. Т. 3: Произведения для детей. $351 \mathrm{c}$.

14 Хе Хифан, Тан Гуангхуи. «Хеисе еумо» де шенмеи хинли йижи хинтан // Бинжоу шижуан хуебао. 2003. № 3. С. 42-45.

15 Щепенко М. Г. Ложь под личиной правды: о теории народно-смеховой культуры М. М. Бахтина // Москва. 2010. № 3. С. 179-192.

16 Эпушитан М. Ханг Йингю Пер. Ксианфенг жуыи ю цонгйиао // Елуози веныи. 2019. № 1. С. 4-14. 
17 Ямпольский М. Беспамятство как исток (Читая Хармса). М.: Новое литературное обозрение, 1998. 379 с.

18 Cornwell N. Daniil Kharms and the poetics of the absurd: essays and materials. London: Palgrave macmillan, 1991. 282 p.

19 Gibian G. Russia's lost literature of the absurd, a literary discovery: selected works of Daniil Kharms and Alexander Vvedensky. Cornell, 1971, 208 p. // Publication of the Association of College and Research Libraries. 1972. Vol. 8, № 11. P. 1458.

20 Harms D. Blue Notebook: Selected stories. St. Petersburg: KAPO, 2009. 104 p.

21 Jakovljevic B. Daniil Kharms: Writing and the event. Evanston: Northwestern university press, 2009. 298 p.

22 Shipley T. J. Dictionary of World Literature - Criticism, Forms, Technique. N.Y.: Philosophical library, 1953. 453 p.

\section{REFERENCES}

1 Bakhtin M. M. Sobranie sochinenii: v 7 t. [Collected Works: in 7 vols.]. Moscow, Russkie slovari Publ., 2008. Vol. 4 (1): Fransua Rable v istorii realizma (1940 g.); Materialy k knige o Rable (1930-1950-e gg.) [Francois Rabelais in the history of realism (1940); Materials for the book about Rabelais (1930-1950s)]. 1119 p. (In Russian)

2 Borisov S. B. Estetika "chernogo iumora" v rossiiskoi traditsii [Aesthetics of "black humor" in the Russian tradition]. In: Iz istorii russkoi esteticheskoi mysli: mezhvuzovskii sbornik nauchnykh trudov [From the history of Russian aesthetic thought: interuniversity collection of scientific papers]. D-harms.ru Available at: http://www.d-harms.ru/library/estetika-chernogo-umora-v-rossiyskoy-traditsii.html (accessed 01 May 2020). (In Russian)

3 Gerasimova A. G. Problema smeshnogo v tvorchestve oberiutov [The problem of the funny in the work of the Oberiuts: PhD thesis, summary]. Moscow, 1988. 26 p. (In Russian)

4 Kobrinskii A. A. Daniil Kharms [Daniil Kharms]. Moscow, Molodaia gvardiia Publ., 2008. 501 p. (In Russian)

5 Kozlova S., Kuliapin A. Ottsy $i$ deti v mire "Chernogo iumora": D. Kharms $i$ $O$. Grigor'ev [Fathers and sons in the world of "black humor": D. Kharms and O. Grigoriev]. Russkaia literatura v XX veke: imena, problemy, kul'turnyi dialog, 2008, no 9, pp. 92-109. (In Russian)

6 Lipavskij L., Vvedenskij A., Druskin Ja. i dr.. “...Sborishhe druzej, ostavlennyh sud'boju”: "Chinari”" $v$ tekstah, dok. $i$ issled.: v 2 t. [“... A bunch of friends left by fate": "Chinari" in the texts, doc. and res.: in 2 vols.]. Moscow, Ladomir Publ., 2000. Vol. 1. 846 p. Vol. 2. 749 p. (In Russian)

7 Mejlah M. B. Pojezija i mif. Izbrannye stat'i [Poetry and myth. Selected articles], $2^{\text {nd }}$ edition. Moscow, Izdatel'skij dom JaSK Publ., 2018. 1056 p. (In Russian)

8 Meilakh M. B. Put' podrazhaniia Kharmsu neplodotvoren [The way of imitation of Kharms is not fruitful]. In: Kommersant [Kommersant]. Available at: https://www. kommersant.ru/doc/639417 (accessed 05 June 2020). (In Russian)

9 Nikoliukin A. N. Literaturnaia entsiklopediia terminov $i$ poniatii [Encyclopedia of literary terms and concepts]. Moscow, NPK "Intelvak" Publ., 2001. 1596 p. (In Russian) 
10 Tokarev D. V. Kurs na khudshee: Absurd kak kategoriia teksta u Daniila Kharmsa i Semiuelia Bekketa [Course for the worst: The absurd as a category of text by Daniil Kharms and Samuel Beckett]. Moscow, Novoe literaturnoe obozrenie Publ., 2002. 333 p. (In Russian)

11 Fedorov G. A. Moskovskii mir Dostoevskogo. Iz istorii russkoi khudozhestvennoi kul'tury XX veka [The Moscow world of Dostoevsky. From the history of Russian artistic culture of the 20 $0^{\text {th }}$ century]. Moscow, Iazyki slavianskoi kul'tury Publ., 2004. 464 p. (In Russian)

12 Kharms D. I. Polnoe sobranie sochinenii: in 4 t. [Complete works: in 4 vols.]. St. Petersburg, Akademicheskii proekt Publ., 2001. Vol. 4: Neizdannyi Kharms. Dopolneniia $k$ t. 1-3: Traktaty $i$ stat'i. Pis'ma [Unpublished Kharms. Additions to vols. 1-3: Treatises and statistics. Letters.]. 319 p. (In Russian)

13 Kharms D. I. Polnoe sobranie sochinenii: $v 4$ t. [Complete works: in 4 vols.] St. Petersburg, Akademicheskii proekt Publ., 1997. Vol. 3: Proizvedeniia dlia detei [Works for children]. 351 p. (In Russian)

14 He Xifan, Tan Guanghui. "Kheise eumo" de shenmei khinli iizhi khintan [New probe into aesthetic mental mechanism of black humour]. Binzhou shizhuan khuebao, 2003, no 3, pp. 42-45. (In Chinese)

15 Shchepenko M. G. Lozh' pod lichinoi pravdy: o teorii narodno-smekhovoi kul'tury M. M. Bakhtina [Lies under the guise of truth: on the theory of folk-laughter culture of M. M. Bakhtin]. Moscow, 2010, no 3, pp. 179-192. (In Russian)

16 Epstein M. Khang Iingiu Per. Ksianfeng zhuyi iu tsongiiao [Avant-garde and Religion]. Eluozi venyi, 2019, no 1, pp. 4-14. (In Chinese)

17 Jampol'skij M. Bespamiatstvo kak istok (Chitaia Kharmsa) [Unconsciousness as a source (Reading Kharms)]. Moscow, Novoe literaturnoe obozrenie, 1998. 379 p. (In Russian)

18 Cornwell N. Daniil Kharms and the poetics of the absurd: essays and materials. London, Palgrave macmillan Publ., 1991. 282 p. (In English)

19 Gibian G. Russia's lost literature of the absurd, a literary discovery: selected works of Daniil Kharms and Alexander Vvedensky. Cornell, 1971. 208 p. In: Publication of the Association of College and Research Libraries, 1972, vol. 8, no 11, p. 1458. (In English)

20 Harms D. Blue Notebook: Selected stories. St. Petersburg, Karo Publ., 2009. 104 p. (In English)

21 Jakovljevic B. Daniil Kharms: Writing and the event. Evanston, Northwestern university press Publ., 2009. 298 p. (In English)

22 Shipley T. J. Dictionary of World Literature - Criticism, Forms, Technique. New York, Philosophical library Publ., 1953. 453 p. (In English) 